\title{
Weed Population Dynamics as Influenced by Seed Rates and Herbicides Application Under Rain fed Wheat (Triticum aestivum L.) Production System
}

\author{
Bogale Ayana \\ Ethiopian Institute of Agricultural Research, Holeta Agricultural Research Center, \\ P.O. BOX 2003, Addis Ababa, Ethiopia
}

\begin{abstract}
Wheat is one of the most important food security crops which is cultivated from small to large scale farms in Ethiopia. However, its productivity has been limited due to various abiotic and biotic factors including weeds. The aim of the study was to investigate the effects of seed rates and post emergence herbicides application on weed management and productivity of wheat. Factorial combinations of three levels of seed rates $(100,150$ and $200 \mathrm{~kg}$ $\mathrm{ha}^{-1}$ )and four types of herbicides (Agro 2,4-D $720 \mathrm{~g} / \mathrm{L} \mathrm{1lt} \mathrm{ha-1}$,Pallas 45 OD 0.5lt ha ${ }^{-1}$, Derby 175 SC $100 \mathrm{ml} \mathrm{ha}^{-1}$ and Lancolet $450 \mathrm{WG} 33 \mathrm{gm} \mathrm{ha}^{-1}$ )along with control (a weedy check) were laid out in RCBD with three replications. The field was infested with thee grass weeds and nine broad leaved weed species. Weeds species included Phalais paradoxa L.,Setaria pumila L. and Arthraxon prinodes L. were categorized as grass weed while Polygonum nepalense L., Raphanus raphanistrum L., Plantago lanceoleta L., Corrigiola capensis Wild., Spergula arvensis L., Galinsoga pulviflora Cav., Guizotia scabra (Vis)Chiov, Cyanotis barbata D.Don and Oxalis corniculata HBK. The relative weed density indicated that from the total of identified 12 weed species identified $86 \%$ broad leaf weeds and $14 \%$ grass weeds. Results also revealed that significant effects of seed rate by herbicide interaction for all the traits studied. It was observed that the application of $150 \mathrm{~kg} \mathrm{ha}^{-1}$ seed rate with Pallas 45 OD resulted in minimum weed densities of all weed species after application while the maximum weed densities were recorded at weedy checks. The minimum weed densities $\left(4.52 \mathrm{~m}^{-2}\right)$ at 25 days after planting (DAP).Longer duration of days to heading was recorded at weedy checks but there is no much significant variation due to other interactions. The maximum plant height was recorded from application of $100 \mathrm{~kg} \mathrm{ha}^{-1}$ seed rate at weedy check. The highest number of grain yield $\left(4516.42 \mathrm{~kg} \mathrm{ha}^{-1}\right)$ was recorded from the combination of $150 \mathrm{~kg} \mathrm{ha}^{-1}$ seed rate with Pallas 45 OD while the lowest values were observed from the weedy check. It was also observed that, the combined use of seed rate $150 \mathrm{~kg} \mathrm{ha}^{-1}$ with Pallas 45 OD effectively managed weeds, economical and gave maximum yields, which could be recommended for the test environment. Since the experiment was conducted in one location and for a single season, it should be repeated over seasons or multi locations for best recommendation.
\end{abstract} Keywords: combination, density, maximum, Pallas 45 OD , significant

DOI: $10.7176 / \mathrm{JEES} / 10-3-04$

Publication date:March $31^{\text {st }} 2020$

\section{INTRODUCTION}

Bread wheat (Triticum aestivum L.) is the most important cereal among the food grain crops in the world( Dalga,2016).It is produced in a wide range of climatic environments and geographic regions (Dixon et al., 2009). Wheat occupies about $17 \%$ of the world's cropped land and contributes $35 \%$ of the staple foods, so its increased production is essential for food security (Shamsi, et.al, 2006). Wheat is one of the major cereal crops grown in the Ethiopian highlands (Hailu, 2003).Despite its importance in Ethiopia, the mean national yield is 2.73 tons $\mathrm{ha}^{-1}$ which is $24 \%$ below the mean yield of Africa and $48 \%$ below the global mean yield of wheat (CSA,2018). Weeds are one of the major constraints in wheat production as they reduce productivity due to competition, allelopathy and by providing habitats for pathogens as well as serving as alternate host for various insects, fungi and increase harvest cost (Abbas et al.,2009). Studies indicated that crop losses due to weed competition throughout the world as a whole are greater than those resulting from combined effect of insect pests and diseases.It causes yield reduction in wheat from 10- 65\% (Genene and Habtamu, 2001). The losses caused by weed infestations vary depending up on the weed species, their density and environmental factors.

Seeding rate, percent viability and germination of seeds usually determine crop density and normally higher the density of a crop, lower is weed competition and vice-verse.The crop density however, cannot be increased arbitrarily and infinitely since every crop has an optimum population beyond which intraspecific competition among crop plants may begin.

Plant stand design is a key parameter for the outcome of weed suppression and grain yield quantity and quality (Kristensen et al., 2008; Kolb et al., 2010 ). Recommended seed rates are optimized for the row distance normally used. Increasing the row distance without a seed rate reduction decreases the distance between individual seeds thereby increasing intraspecific and inter specific competition between plants. A common assumption is that seed rate should be reduced when row distance is increased although the optimal magnitude of the reduction is poorly 
known. Thus, better arrangement of crops with optimum seed rates to agro-ecological condition can be a feasible option in improving the wheat productivity .

Physical methods are laborious,tiresome and expensive due to increasing cost of labor, draft animals and implements. Weeds cannot effectively be managed merely due to crop mimicry therefore, the use chemical weed control has become necessary (Marwat et al.,2008). However, the choice of most appropriate herbicide, proper time of application and proper dose is an important consideration for lucrative returns (Khalil, et al., 2008). Application of herbicides decreased dry weight of weeds significantly compared to dry weight in non treated plots and increased yield components and grain yield (Bibi, et al., 2008).

As alternatives, current weed control strategies concentrate on integrated weed control programs include crop rotation, mechanical practices, cultivation,hand weeding and herbicide use.The development of integrated weed management system however, requires detailed information on weed crop interactions including the relative competitive ability of the crop and weeds during various phases of development.Therefore, the aim of the study was to determine optimum seed rates and identify suitable herbicides for the management of weeds in wheat.

\section{MATERIALS AND METHODS}

\section{Description of the study area}

Field experiment was conducted during the 2018/19 main cropping season under rain fed conditions at Holeta Agricultural Research Center. Holeta is located $33 \mathrm{~km}$ west of Addis Ababa at an elevation of 2400m.a.s.1 and within the geographic coordinates of $9^{\circ} 0{ }^{\circ} \mathrm{N}$ and $38^{\circ} 3^{\circ} \mathrm{E}$. The area receives annual rain fall of $1144 \mathrm{~mm}$ with mean minimum and maximum temperatures of $6^{\circ} \mathrm{c}$ and $22^{\circ} \mathrm{C}$, respectively (EIAR,2018). The soil of the experimental field is clay loam with $\mathrm{pH}$ of 6.65 , organic carbon $(2.26 \%)$, available Phosphorus $\left(14.17 \mathrm{mg} \mathrm{kg}^{-}\right.$ $\left.{ }^{1}\right)$, total nitrogen $(0.12 \%)$ and cation exchange capacity of $\left(17 \mathrm{Cmol} \mathrm{kg}^{-1}\right)$ (EIAR,2018). The edaphic and climatic conditions observed during the trial period were favorable for the exuberant growth of numerous weed species that competed with the crop plants.

\section{Treatments and experimental design}

The experimental materials used in the experiment were popular bread wheat variety Dendea and four types of broad leaf herbicides that were registered in Ethiopia for the control of annual leaf weeds. The treatments included factorial combinations of three levels of seeding rates $\left(100,150\right.$ and $\left.200 \mathrm{~kg} \mathrm{ha}^{-1}\right)$ and four types post emergence herbicides (Agro 2,4-D amine 720g/L, Pallas 45 OD, Derby 175 SC, Lancolet 450 WG plus weedy check that was laid out in a Randomized Complete Block Design with three replications.

\section{Experimental procedure and crop management}

The field was ploughed twice with tractor followed by harrowing to make fine seed bed. Gross plot sizes of $4 \mathrm{~m} \mathrm{x}$ $3 \mathrm{~m}\left(12 \mathrm{~m}^{2}\right)$ was used as the experimental unit accommodating 15 rows of each $4 \mathrm{~m}$ long. Seeds were drill planted in rows at $20 \mathrm{~cm}$ spacing between rows on July 17, 2018. The experimental area was fertilized with the recommended rate of $55 \mathrm{~kg} \mathrm{ha}^{-1}$ of $\mathrm{N}$ and $182 \mathrm{~kg} \mathrm{ha}^{-1}$ of $\mathrm{P}_{2} \mathrm{O}_{5}$ that were applied in the form of Urea (46\% N) and DAP $\left(18 \% \mathrm{~N}, 46 \% \mathrm{P}_{2} \mathrm{O}_{5}\right)$, respectively. Nitrogen fertilizer was applied at two doses (split application) i. e $2 / 3$ of it was applied at time of sowing by mixing with full dose of Nitrogen and the remaining 1/3 was applied at tillering stage. Herbicides were applied at post emergence stage (30 DAE) with the help of knapsack sprayer nozzle size of $350 \mathrm{um}$ while the volume of water was $200 \mathrm{~L} / \mathrm{ha}^{-1}$ pressurized at $40 \mathrm{psi}$.All other management practices were uniformly applied to all plots as per the recommended practices.

\section{Data collection}

Weed species identification was done by uprooting fresh weeds from experimental field and taken to laboratory. After the weed flora were identified, they were categorized as grasses and broad leaf weeds reference of manuals, Consulting experienced professionals and comparing with existed herbarium as described by Stroud and Parker (1989). Data regarding the kind of weed species and their densities were counted at 25 day after sowing i. e, before the application of herbicides by using four quadrates with sizes of $0.25 \mathrm{~m} \mathrm{x} 0.25 \mathrm{~m}$ randomly placed in each plot and their density was calculated $\mathrm{m}^{-2}$. In addition, individual weed species density count was also done at 25 and 45 days after herbicides were applied by randomly placing four quadrates of sizes $0.25 \mathrm{~m} \times 0.25 \mathrm{~m}$ converted to $\mathrm{m}^{-2}$. Days to heading was recorded as the number of days from sowing to the day when plants reached heading based on visual observation.Plant height was taken with a meter from 4 randomly taken and pre-tagged plants in each net plot area from the plant base to the tip of the spike excluding of awns at physiological maturity and the average was used for the analysis. Spike length was taken with a ruler from 4 randomly taken and pre-tagged plants in each net plot area from the base of the spike to the tip of the spike excluding of awns at physiological maturity and the average was used for the analysis. Grain yield was measured after threshing the sun dried plants harvested from each net plot and the yield was adjusted at 12.5\% grain moisture content (Amare et al., 2014).

\section{Statistical analysis}

The means of each data was checked by the normality test depending on Shapiro test $(\operatorname{Pr}<\mathrm{W})$ before analysis of variance using the GLM procedure of SAS (SAS 9.3 version). When the treatment effects were significant, means were compared using Fisher's LSD test at 5\% level of significance (Gomez and Gomez, 1984).Correlations 
between traits were also analyzed using Pearson's correlation coefficients in SAS (Gomez and Gomez, 1984).

\section{RESULTS AND DISCUSSION}

\section{Composition of weed flora and density in the experimental field}

The weed community comprised of both broadleaf and grass weeds which were classified in to eight major families. Out of total weeds species present in the experimental field $86 \%$ were annual broadleaf weeds while $14 \%$ were annual grasses weeds. The maximum relative weed density in the field was G. pulviflora $(22.84 \%)$ followed by $P$. nepalense $(18.72 \%)$ while minimum relative weed density $(0.98 \%)$ was recorded from $G$. scabra (Table - 1 ).

Table 1. Categories of the identified weed species and their densities in the experimental field

\begin{tabular}{lllll}
\hline Scientific names & Families & $\begin{array}{l}\text { Weed density } \\
\mathrm{m}^{-2} \text { before spray }\end{array}$ & $\begin{array}{l}\text { Relative } \\
\text { Weed } \\
\text { Density } \\
(\%)\end{array}$ & Life form/category \\
& & & 5.11 & Annual (grass) \\
\hline $\begin{array}{l}\text { Arthraxon prinodes } \text { L. } \\
\text { Setaria pumila } \text { L. }\end{array}$ & Poaceae & 21.06 & 7.59 & Annual (grass) \\
Phalaris paradoxa L. & Poaceae & 31.33 & 1.31 & Annual (grass) \\
Galinsoga pulviflora Cav. & Poaceae & 5.39 & 22.84 & Annual (broad leaf) \\
Corrigiola capensis Wild & Compositae & 94.18 & 11.81 & Annual (broad leaf) \\
Guizotia scabra (Vis)Chiov & Compositace & 48.71 & 0.98 & Annual (broad leaf) \\
Oxalis corniculata HBK & Oxalidaceae & 28 & 6.77 & Annual (broad leaf) \\
Plantago lanceoleta L. & Plantaginaceae & 19.1 & 4.62 & Annual (broad leaf) \\
Polygonum nepalense L. & Polygonaceae & 77.2 & 18.72 & Annual (broad leaf) \\
Raphanus raphanistrum L. & Brassicaceae & 15.5 & 3.76 & Annual (broad leaf) \\
Spergula arvensis L. & Caryophylaceae & 20 & 4.85 & Annual (broad leaf) \\
Cyanotis barbata D.Don & Commelinaceae & 47.7 & 11.57 & Annual (broad leaf) \\
\hline
\end{tabular}

The result indicated that variation of weed flora composition could be depending on amount of weed seed bank in the soil, germination capacity and favorable environmental conditions. Abraham (2006) also reported that weed growth, population density and distributions in cereal fields vary from place to place depending upon soil and climatic factors and management practices.

\section{Effects of seed rates and herbicides application on weed densities after application}

Polygonum nepalense $\mathrm{L}$.

The main effects of seed rates, herbicides and their interaction was significant on density of P. nepalense after herbicides application ( Table - 2). Minimum weeds density $2.48 \mathrm{~m}^{-2}$ of $P$. nepalense was recorded from interaction of $150 \mathrm{~kg} \mathrm{ha}^{-1}$ seed rate with Pallas $45 \mathrm{OD}$ while the maximum number was obtained from $100 \mathrm{~kg} \mathrm{ha}^{-1}$ seed rate at weedy check. The application of $100 \mathrm{~kg} \mathrm{ha}^{-1}$ seed rate with all herbicides except Pallas 45 OD statistically showed that no significant as well as the application of $150 \mathrm{~kg} \mathrm{ha}^{-1}$ seed rate with all herbicides except Lancolet $450 \mathrm{WG}$ caused no significant difference. Moreover, the combined effects of $200 \mathrm{~kg} \mathrm{ha}^{-1}$ with Derby $175 \mathrm{SC}$ and Lancolet 450WG showed no significant difference.

Raphanus raphanistrum $\mathrm{L}$.

The main effects of seed rates, herbicides and their interaction on density of $R$. raphanistrum was significant on weed density after herbicides application (Table-2). Minimum weeds density $2.46 \mathrm{~m}^{-2}$ of $R$. raphanistrum was recorded from interaction of $150 \mathrm{~kg} \mathrm{ha}^{-1}$ seed rate with Pallas 45 OD while the maximum number was obtained from $100 \mathrm{~kg} \mathrm{ha}^{-1}$ seed rate at weedy check. he interaction effects of $100 \mathrm{~kg} \mathrm{ha}^{-1}$ with all herbicides revealed that statistically no significant difference except Pallas $45 \mathrm{OD}$ and also the interaction effects of $150 \mathrm{~kg} \mathrm{ha}^{-1}$ seed rate with all herbicides except for Lancolet $450 \mathrm{WG}$ revealed that statistically no significant difference. Furthermore, the interaction of $200 \mathrm{~kg} \mathrm{ha}^{-1}$ seed rate with 2, 4-D and Pallas $45 \mathrm{OD}$ caused no significant difference. Correspondingly, the application of $200 \mathrm{~kg} \mathrm{ha}^{-1}$ seed rate with Derby $175 \mathrm{SC}$ and Lancolet 450 WG caused no significant difference.

\section{Plantago lanceoleta $\mathrm{L}$.}

The main effect of seed rates, herbicides and their interaction was significant on density of P. lanceoleta after herbicides application (Table - 2). Minimum weeds density $2.5 \mathrm{~m}^{-2}$ of $P$. lanceoleta was recorded from interaction of $150 \mathrm{~kg} \mathrm{ha}^{-1}$ seed rate with Pallas $45 \mathrm{OD}$ while the maximum number was obtained from $100 \mathrm{~kg} \mathrm{ha}^{-1}$ seed rate at weedy check. The application of $100 \mathrm{~kg} \mathrm{ha}^{-1}$ seed rate with all herbicides except Pallas 45 OD resulted no significant difference and also the interaction effects of $150 \mathrm{~kg} \mathrm{ha}^{-1}$ seed rate with the combination of $200 \mathrm{~kg} \mathrm{ha}^{-1}$ seed rate with 2,4-D and Derby $175 \mathrm{SC}$ caused statistically no significant difference. Similarly, the application of $200 \mathrm{~kg} \mathrm{ha}^{-1}$ seed rate with Pallas 45 OD and Lancolet $450 \mathrm{WG}$ caused no significant difference.

Cyanotis barbata D.Don

The main effect of seed rates, herbicides and their interaction was significant on density of C. barbata after herbicides application (Table-2). Minimum weeds density $3.05 \mathrm{~m}^{-2}$ of C. barbata was recorded from interaction 
of $150 \mathrm{~kg} \mathrm{ha}^{-1}$ seed rate with Pallas 45 OD while the maximum number was obtained from $100 \mathrm{~kg} \mathrm{ha}^{-1}$ seed rate at weedy check. The application of $100 \mathrm{~kg} \mathrm{ha}^{-1}$ seed rate with all herbicides application showed that statistically no significant difference. Similarly, the application of $150 \mathrm{~kg} \mathrm{ha}^{-1}$ seed rate with 2,4 -D and Pallas 45 OD showed that no significant difference. Moreover, the application of $150 \mathrm{~kg} \mathrm{ha}^{-1}$ seed rate with Derby and Lancolet 450 WG caused no significant difference. Moreover, the application of $200 \mathrm{~kg} \mathrm{ha}^{-1}$ seed rate with all herbicides except 2 , 4-D caused no significant difference.

\section{Corrigiola capensis Wild}

The main effect of seed rates, herbicides and their interaction was significant on density of C. capensis after herbicides application (Table-2). Minimum weeds density $3.1 \mathrm{~m}^{-2}$ of $C$. capensis was recorded from interaction of $150 \mathrm{~kg} \mathrm{ha}^{-1}$ seed rate with Pallas $45 \mathrm{OD}$ while the maximum number was obtained from $100 \mathrm{~kg} \mathrm{ha}^{-1}$ seed rate at weedy check. The application of $100 \mathrm{~kg} \mathrm{ha}^{-1}$ seed rate with Derby $175 \mathrm{SC}$ and Lancolet $450 \mathrm{WG}$ showed that no significant difference. Similarly, the application of $150 \mathrm{~kg} \mathrm{ha}^{-1}$ seed rate with 2, 4-D and Lancolet showed that no significant difference. Moreover, the application of $150 \mathrm{~kg} \mathrm{ha}^{-1}$ seed rate with Pallas 45 OD and Derby $175 \mathrm{SC}$ caused statistically no significant difference. The application of $200 \mathrm{~kg} \mathrm{ha}^{-1}$ seed rate with all herbicides except 2 , 4-D and Lancolet $450 \mathrm{WG}$ caused statistically no significant difference. Similarly, the application of $200 \mathrm{~kg} \mathrm{ha}^{-1}$ with Pallas 45 OD and Derby 175 SC resulted no significant difference.

Table 2.The effect of seed rates and herbicides on individual weed densities after application

\begin{tabular}{|c|c|c|c|c|c|c|c|c|c|c|c|c|}
\hline 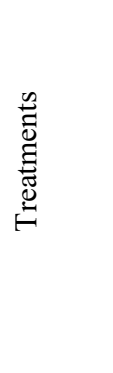 & 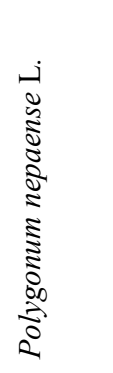 & 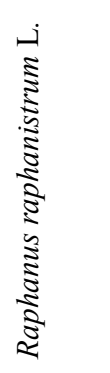 & 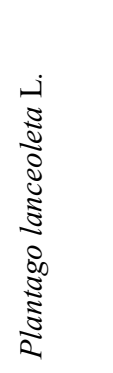 & 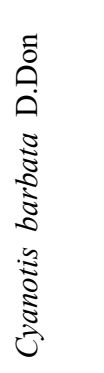 & 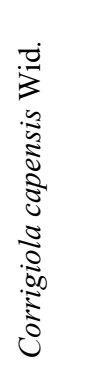 & 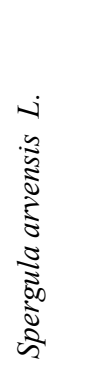 & $\begin{array}{c}\overrightarrow{0} \\
0 \\
0 \\
0 \\
0 \\
0 \\
0 \\
0 \\
0 \\
0 \\
0 \\
0 \\
0 \\
0 \\
0 \\
0\end{array}$ & 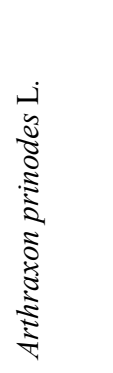 & 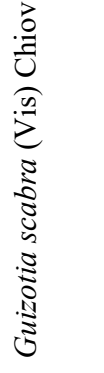 & 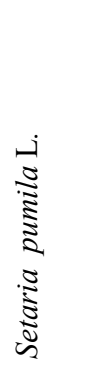 & 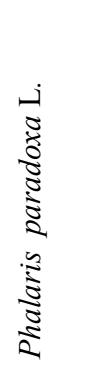 & 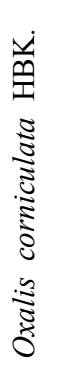 \\
\hline $\mathrm{S}_{1} * \mathrm{~W}_{1}$ & $3.33^{\mathrm{cd}}$ & $3.18^{\mathrm{cde}}$ & $3.29^{\mathrm{bc}}$ & $3.83^{b c}$ & $3.75^{\mathrm{d}}$ & $3.66^{\mathrm{d}}$ & $3.7^{\mathrm{cd}}$ & $3.71^{b c}$ & $3.65^{\mathrm{c}}$ & $2.43^{\mathrm{c}}$ & $2.41^{\mathrm{c}}$ & $3.68^{\mathrm{bc}}$ \\
\hline $\mathrm{S}_{1} * \mathrm{~W}_{2}$ & $2.86^{\mathrm{def}}$ & $2.81^{\mathrm{ef}}$ & $3.18^{\mathrm{bcd}}$ & $3.85^{\mathrm{b}}$ & $3.21^{\mathrm{f}}$ & $3.2^{\mathrm{g}}$ & $3.25^{\mathrm{fg}}$ & $3.7^{\mathrm{bc}}$ & $3.29^{\mathrm{f}}$ & $2.16^{\mathrm{cde}}$ & $2.06^{\mathrm{cde}}$ & $3.25^{\mathrm{f}}$ \\
\hline $\mathrm{S}_{1} * \mathrm{~W}_{3}$ & $3.56^{c}$ & $3.5^{\mathrm{c}}$ & $3.43^{b}$ & $3.75^{b c}$ & $3.5^{\mathrm{e}}$ & $3.51^{\mathrm{e}}$ & $3.48^{\mathrm{de}}$ & $3.46^{\text {cdef }}$ & $3.36^{\mathrm{ef}}$ & $2.3^{\mathrm{cd}}$ & $2.41^{\mathrm{c}}$ & $3.48^{\mathrm{de}}$ \\
\hline $\mathrm{S}_{1} * \mathrm{~W}_{4}$ & $3.3^{\text {cde }}$ & $3.36^{\mathrm{c}}$ & $2.83^{\text {cde }}$ & $3.51^{\mathrm{bcd}}$ & $3.65^{\mathrm{e}}$ & $3.63^{\mathrm{e}}$ & $3.62^{\mathrm{de}}$ & $3.58^{b c}$ & $3.56^{\text {cde }}$ & $2.13^{\text {cde }}$ & $2.16^{\text {cde }}$ & $3.6^{\mathrm{cd}}$ \\
\hline $\mathrm{S}_{1} * \mathrm{~W}_{5}$ & $5.16^{\mathrm{a}}$ & $2.76^{\mathrm{ef}}$ & $4.55^{\mathrm{a}}$ & $4.95^{\mathrm{a}}$ & $4.36^{\mathrm{a}}$ & $4.4^{\mathrm{a}}$ & $4.58^{\mathrm{a}}$ & $4.63^{\mathrm{a}}$ & $4.61^{\mathrm{a}}$ & $3.91 \mathrm{a}$ & $3.95 \mathrm{a}$ & $4.41^{\mathrm{a}}$ \\
\hline $\mathrm{S}_{2} * \mathrm{~W}_{1}$ & $2.75^{\mathrm{fg}}$ & $2.76^{\mathrm{ef}}$ & $3.18^{\text {bcd }}$ & $2.88^{f}$ & $3.68^{\mathrm{d}}$ & $3.61^{\mathrm{e}}$ & $3.63^{\mathrm{de}}$ & $3.62^{\mathrm{bcd}}$ & $3.38^{\mathrm{def}}$ & $2.08^{\text {cde }}$ & $2.08^{\text {cde }}$ & $3.61^{\mathrm{cd}}$ \\
\hline $\mathrm{S}_{2} * \mathrm{~W}_{2}$ & $2.48^{\mathrm{g}}$ & $2.46^{\mathrm{f}}$ & $2.5^{\mathrm{e}}$ & $3.05^{\mathrm{ef}}$ & $3.1^{\mathrm{f}}$ & $3.18^{\mathrm{g}}$ & $3.11^{\mathrm{g}}$ & $3.25^{\mathrm{ef}}$ & $3.22^{\mathrm{f}}$ & $1.41^{\mathrm{fgh}}$ & $1.41^{\mathrm{fg}}$ & $3.2^{\mathrm{f}}$ \\
\hline $\mathrm{S}_{2} * \mathrm{~W}_{3}$ & $2.78^{\mathrm{fg}}$ & $2.76^{\mathrm{ef}}$ & $2.75^{\mathrm{de}}$ & $3.41^{\text {cde }}$ & $3.21^{\mathrm{f}}$ & $3.21^{\mathrm{g}}$ & $3.24^{\mathrm{fg}}$ & $3.19^{\mathrm{bcd}}$ & $3.25^{f}$ & $1.88^{\mathrm{de}}$ & $2.03^{\text {cde }}$ & $3.29^{\mathrm{ef}}$ \\
\hline $\mathrm{S}_{2} * \mathrm{~W}_{4}$ & $3.25^{\text {cdef }}$ & $3.19^{\text {cde }}$ & $3.01^{\text {bcde }}$ & $3.21^{\mathrm{def}}$ & $3.63^{\mathrm{e}}$ & $3.58^{\mathrm{e}}$ & $3.62^{\mathrm{de}}$ & $3.56^{\text {bcde }}$ & $3.54^{\text {cde }}$ & $1.78^{\mathrm{efg}}$ & $1.78^{\mathrm{def}}$ & $3.46^{\mathrm{de}}$ \\
\hline $\mathrm{S}_{2} * \mathrm{~W}_{5}$ & $4.66^{\mathrm{ab}}$ & $4.61^{b}$ & $4.23^{\mathrm{a}}$ & $3.91^{\mathrm{b}}$ & $4.13^{b}$ & $4.16^{\mathrm{b}}$ & $4.2^{\mathrm{b}}$ & $4.3^{\mathrm{a}}$ & $4.38^{\mathrm{a}}$ & $3.83^{\mathrm{ab}}$ & $3.66^{\mathrm{ab}}$ & $4.26^{\mathrm{a}}$ \\
\hline $\mathrm{S}_{3} * \mathrm{~W}_{1}$ & $2.81^{\mathrm{efg}}$ & $2.86^{\mathrm{def}}$ & $3.34^{\mathrm{bc}}$ & $3.51^{\mathrm{bcd}}$ & $3.48^{\mathrm{e}}$ & $3.46^{\mathrm{ef}}$ & $3.7^{\mathrm{cd}}$ & $3.56^{\mathrm{bc}}$ & $3.61^{\mathrm{cd}}$ & $1.86^{\mathrm{def}}$ & $1.73^{\mathrm{def}}$ & $3.54^{\mathrm{cd}}$ \\
\hline $\mathrm{S}_{3} * \mathrm{~W}_{2}$ & $2.53^{\mathrm{g}}$ & $2.53^{\mathrm{f}}$ & $2.68^{\mathrm{de}}$ & $3.08^{\mathrm{ef}}$ & $3.23^{\mathrm{f}}$ & $3.3^{\mathrm{fg}}$ & $3.24^{\mathrm{fg}}$ & $3.34^{\text {cdef }}$ & $3.22^{f}$ & $1.16^{\mathrm{h}}$ & $1.1^{\mathrm{g}}$ & $3.31^{\mathrm{ef}}$ \\
\hline $\mathrm{S}_{3} * \mathrm{~W}_{3}$ & $3.32^{\text {cde }}$ & $3.3^{\text {cd }}$ & $3.4^{\mathrm{b}}$ & $3.2^{\mathrm{def}}$ & $3.21^{\mathrm{f}}$ & $3.25^{\mathrm{g}}$ & $3.23^{\mathrm{fg}}$ & $3.26^{\mathrm{def}}$ & $3.22^{\mathrm{f}}$ & $1.38^{\mathrm{gh}}$ & $1.71^{\mathrm{ef}}$ & $3.23^{\mathrm{f}}$ \\
\hline $\mathrm{S}_{3} * \mathrm{~W}_{4}$ & $3.15^{\text {cde }}$ & $3.16^{\text {cde }}$ & $2.96^{\text {bcde }}$ & $3.25^{\mathrm{def}}$ & $3.48^{\mathrm{e}}$ & $3.45^{\mathrm{ef}}$ & $3.45^{\mathrm{ef}}$ & $3.42^{\text {cdef }}$ & $3.37^{\mathrm{ef}}$ & $2.11^{\text {cde }}$ & $2.21^{\mathrm{cd}}$ & $3.34^{\mathrm{ef}}$ \\
\hline $\mathrm{S}_{3} * \mathrm{~W}_{5}$ & $4.5^{\mathrm{b}}$ & $4.5^{\mathrm{a}}$ & $4.18^{\mathrm{a}}$ & $3.86^{\mathrm{b}}$ & $3.86^{\mathrm{c}}$ & $3.88^{\mathrm{c}}$ & $3.88^{\mathrm{c}}$ & $3.9^{\mathrm{b}}$ & $3.9^{\mathrm{b}}$ & $3.41^{\mathrm{b}}$ & $3.41^{\mathrm{b}}$ & $3.86^{\mathrm{b}}$ \\
\hline $\operatorname{LSD}(5)$ & 0.5 & 0.46 & 0.54 & 0.43 & 0.17 & 0.18 & 0.22 & 0.37 & 0.23 & 0.45 & 0.48 & 0.19 \\
\hline CV\% & 8.97 & 8.34 & 9.91 & 7.28 & 2.9 & 3.14 & 3.69 & 6.1 & 3.92 & 11.96 & 12.86 & 3.21 \\
\hline
\end{tabular}

Means followed by the same letter in the lower case with in columns are not significantly different from each other at $5 \%$ level of significance. $\mathrm{S}_{1}=100 \mathrm{~kg} \mathrm{ha}^{-1}, \mathrm{~S}_{2}=150 \mathrm{~kg} \mathrm{ha}^{-1}, \mathrm{~S}_{3}=200 \mathrm{~kg} \mathrm{ha}^{-1}, \mathrm{~W}_{1}=$ Agro 2, 4-D amine $720 \mathrm{~g} / \mathrm{L}$, $\mathrm{W}_{2}=$ Pallas $45 \mathrm{OD}, \mathrm{W}_{3}=$ Derby $175 \mathrm{SC}, \mathrm{W}_{4}=$ Lancolet $450 \mathrm{WG}$ and $\mathrm{W}_{5}=$ weedy check

Spergula arvensis $\mathbf{L}$.

The main effect of seed rates, herbicides and their interaction was significant on density of S.arvensis after herbicides application (Table - 2). Minimum weeds density $3.18 \mathrm{~m}^{-2}$ of $S$. arvensis was recorded from interaction of $150 \mathrm{~kg} \mathrm{ha}^{-1}$ seed rate with Pallas $45 \mathrm{OD}$ while the maximum number was obtained from $100 \mathrm{~kg} \mathrm{ha}^{-1}$ seed rate at weedy check. The application of $100 \mathrm{~kg} \mathrm{ha}^{-1}$ seed rate with all herbicides except with Pallas 45 OD showed that no significant difference. Similarly, the application of $150 \mathrm{~kg} \mathrm{ha}^{-1}$ seed rate with 2,4-D and Lancolet $450 \mathrm{WG}$ showed that no significant difference. Moreover, the application of $150 \mathrm{~kg} \mathrm{ha}^{-1}$ seed rate with Pallas 45 OD and Derby $175 \mathrm{SC}$ caused no significant difference. The application of $200 \mathrm{~kg} \mathrm{ha}^{-1}$ seed rate with all herbicides except 2, 4- D and Lancolet $450 \mathrm{WG}$ caused no significant effects. Similarly, the application of $200 \mathrm{~kg} \mathrm{ha}^{-1}$ with Pallas $45 \mathrm{OD}$ and Derby $175 \mathrm{SC}$ resulted no significant difference.

Galinsoga pulviflora Cav.

The main effect of seed rates, herbicides and their interaction was significant on density of

G. pulviflora after 
herbicides application (Table-2). Minimum weeds density $3.11 \mathrm{~m}^{-2}$ of

G. pulviflora was recorded from interaction of $150 \mathrm{~kg} \mathrm{ha}^{-1}$ seed rate with Pallas $45 \mathrm{OD}$ while the maximum number was obtained from $100 \mathrm{~kg} \mathrm{ha}^{-1}$ seed rate at weedy check. The application of $100 \mathrm{~kg} \mathrm{ha}^{-1}$ seed rate with all herbicides except with Pallas 45 OD showed that no significant difference on .Similarly, the application of $150 \mathrm{~kg} \mathrm{ha}^{-1}$ seed rate with $2,4-\mathrm{D}$ and Lancolet showed that no significant difference. Moreover, the application of $150 \mathrm{~kg} \mathrm{ha}^{-1}$ seed rate with Pallas 45 OD and Derby 175 SC caused no significant difference. Similarly, the application of $200 \mathrm{~kg} \mathrm{ha}^{-1}$ with Pallas 45 OD and Derby $175 \mathrm{SC}$ resulted no significant difference.

\section{Arthraxon prinodes L.}

The main effect of seed rates, herbicides and their interaction was significant on density of A. prinodes after herbicides application (Table - 2). Minimum weeds density $3.25 \mathrm{~m}^{-2}$ of $A$. prinodes was recorded from interaction of $150 \mathrm{~kg} \mathrm{ha}^{-1}$ seed rate with Pallas $45 \mathrm{OD}$ while the maximum number was obtained from $100 \mathrm{~kg} \mathrm{ha}^{-1}$ seed rate at weedy check. The application of $100 \mathrm{~kg} \mathrm{ha}^{-1}$ seed rate with all herbicides except for weedy check showed that no significant difference. Correspondingly, the application of $150 \mathrm{~kg}$ ha all herbicides except Pallas 45 OD showed that no significant difference. Moreover, the application of $200 \mathrm{~kg} \mathrm{ha}^{-1}$ seed rate with all herbicides except 2, 4-D caused no significant difference.

\section{Guizotia scabra (Vis)Chiov}

The main effect of seed rates, herbicides and their interaction was significant on density of G. scabra after herbicides application (Table - 2). Minimum weeds density $3.22 \mathrm{~m}^{-2}$ of G. scabra was recorded from interaction of $150 \mathrm{~kg} \mathrm{ha}^{-1}$ seed rate with Pallas 45 OD while the maximum number was obtained from $100 \mathrm{~kg} \mathrm{ha}^{-1}$ seed rate at weedy check. The application of $100 \mathrm{~kg} \mathrm{ha}^{-1}$ seed rate with 2,4- D and Lancolet $450 \mathrm{WG}$ showed that no significant difference. Similarly, the application of $100 \mathrm{~kg} \mathrm{ha}^{-1}$ seed rate with Pallas 45 OD and Derby 175 SC showed that no significant difference. Moreover, the application of $150 \mathrm{~kg} \mathrm{ha}^{-1}$ seed rate with Pallas $45 \mathrm{OD}$ and Derby $175 \mathrm{SC}$ caused no significant difference. Correspondingly, the application of $150 \mathrm{~kg} \mathrm{ha}^{-1}$ seed rate with 2, 4-D and Lancolet $450 \mathrm{WG}$ showed that no significant difference. The application of $200 \mathrm{~kg} \mathrm{ha}^{-1}$ seed rate with all herbicides except 2, 4-D showed that no significant difference.

Setaria pumila $\mathrm{L}$.

The main effects of seed rates,herbicides and their interaction was significant on density of $S$. pumila after herbicides application (Table - 2). Minimum weeds density $1.16 \mathrm{~m}^{-2}$ of $S$. pumila was recorded from interaction of $200 \mathrm{~kg} \mathrm{ha}^{-1}$ seed rate with Pallas 45 OD while the maximum number was obtained from interaction of $100 \mathrm{~kg}$ $\mathrm{ha}^{-1}$ seed rate at weedy check. The application of $100 \mathrm{~kg} \mathrm{ha}^{-1}$ seed rate with all herbicides except for weedy check showed that no significant difference .Similarly, the application of $150 \mathrm{~kg} \mathrm{ha}^{-1}$ seed rate with all herbicides except Pallas 45 OD showed that no significant difference. Moreover, the application of $200 \mathrm{~kg} \mathrm{ha}^{-1}$ seed rate with Pallas $45 \mathrm{OD}$ and Derby $175 \mathrm{SC}$ caused no significant difference. Similarly, the application of $200 \mathrm{~kg} \mathrm{ha}^{-1}$ with Pallas 45 OD and Derby $175 \mathrm{SC}$ resulted no significant difference.

Phalaris paradoxa $\mathrm{L}$.

The main effect of seed rates, herbicides and their interaction was significant on density of $P$. paradoxa after herbicides application (Table - 2). Minimum weeds density $1.1 \mathrm{~m}^{-2}$ of $P$. paradoxa was recorded from interaction of $200 \mathrm{~kg} \mathrm{ha}^{-1}$ seed rate with Pallas $45 \mathrm{OD}$ while the maximum number was obtained from $100 \mathrm{~kg} \mathrm{ha}^{-1}$ seed rate at weedy check. The application of $100 \mathrm{~kg} \mathrm{ha}^{-1}$ seed rate with all herbicides except for weedy check showed that no significant difference .Similarly, the application of $150 \mathrm{~kg} \mathrm{ha}^{-1}$ seed rate with all herbicides except Pallas 45 OD showed that no significant difference. Moreover, the application of $200 \mathrm{~kg} \mathrm{ha}^{-1}$ seed rate with 2, 4-D and Derby $175 \mathrm{SC}$ caused no significant difference.

\section{Oxalis corniculata HBK.}

The main effect of seed rates, herbicides and their interaction was significant on weed density after herbicides application (Table -2). Minimum weeds density $3.2 \mathrm{~m}^{-2}$ of $O$. corniculata was recorded from interaction of $150 \mathrm{~kg}$ $\mathrm{ha}^{-1}$ seed rate with Pallas 45 OD while the maximum number was obtained from $100 \mathrm{~kg} \mathrm{ha}^{-1}$ seed rate at weedy check. The application of $100 \mathrm{~kg} \mathrm{ha}^{-1}$ seed rate with Derby $175 \mathrm{SC}$ and Lancolet $450 \mathrm{WG}$ showed that no significant difference. Similarly, the application of $150 \mathrm{~kg} \mathrm{ha}^{-1}$ seed rate with 2, 4-D and Lancolet $450 \mathrm{WG}$ showed that no significant difference. Moreover, the application of $150 \mathrm{~kg} \mathrm{ha}^{-1}$ seed rate with Pallas 45 OD and Derby 175 SC caused statistically no significant difference. Moreover, the application of $200 \mathrm{~kg} \mathrm{ha}^{-1}$ with all except 2, 4-D resulted no significant difference.

The over all results of each weed species revealed that the application of different levels of seed rates with combination of broad spectrum herbicides resulted in decreased weed density per unit area due to limited availability for space consequently resulted decreased growth .The herbicides were also persistent enough and caused the mortality of weeds by affecting the physiological processes.

These results are in line with work of Bibi et al. (2008) who concluded that herbicides significantly affected the weed population per unit area when applied at post-emergence stage of wheat crop.

Effects of seed rates and herbicides on weed density at 25 days after herbicides application in bread wheat The application of different levels seed rates and the interaction showed that significant effect on weeds density 
$\mathrm{m}^{-2}$ at 25 DAP while application of herbicides had no significant effect on weed density (Table - 3). Minimum weeds density $\left(4.52 \mathrm{~m}^{-2}\right)$ was recorded from interaction of $150 \mathrm{~kg} \mathrm{ha}^{-1}$ seed rate with Pallas 45 OD whereas maximum weeds density $\mathrm{m}^{-2}$ was recorded in weedy check plots at all interactions .

This result revealed that there is no statistically significant difference was observed with interaction effects of 2, 4 - D and Pallas 45 OD along with all seed rates. Similarly, the application of $150 \mathrm{~kg} \mathrm{ha}^{-1}$ and $200 \mathrm{~kg} \mathrm{ha}^{-1}$ seed rates with Derby $175 \mathrm{SC}$ and Lancolet $450 \mathrm{WG}$ caused statistically no significant difference. Moreover, the application of all seed rates with all herbicides revealed that statistically no significant difference except for weedy checks.

The interaction of increased seed rates $150 \mathrm{~kg} \mathrm{ha}^{-1}$ in combination with Pallas 45 OD resulted in lower weed density than other interactions could be related to less intra specific competition due to minimum plant density that created better growing condition for weed than crop and the herbicides were not persistent enough to kill growing weeds.

Table 3.The effects of seed rates and herbicides on weed density $\mathbf{m}^{-2}$ at 25 days after herbicides application in bread wheat

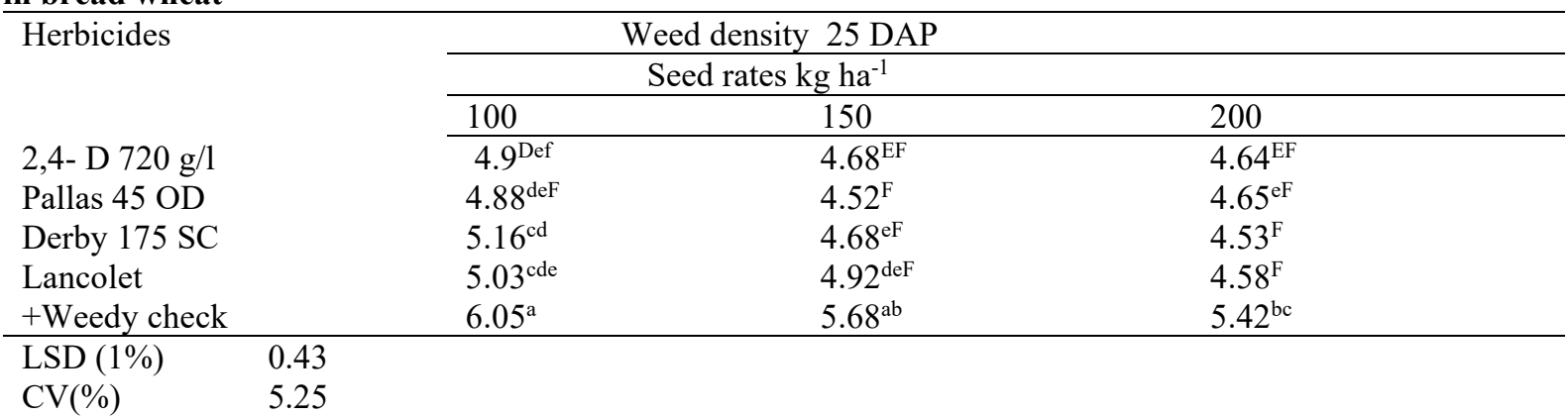

Means followed by the same letter in the upper case with in rows and lower case with in columns are not significantly different from each other at $1 \%$ level of significance

However, for better weed control the effectiveness of tested herbicides could be more than 25 days of application. Similar results were reported from Bibi et al. (2008) who concluded that herbicides significantly affected the weed population per unit area when applied at post emergence stage of wheat crop.

The Effects of seed rates and herbicides application on days to heading in bread wheat

Days to heading was influenced by herbicides application and their interactions but not significantly influenced by the application of different levels of seed rates . The maximum days to heading was recorded in the interaction of $100 \mathrm{~kg} \mathrm{ha}^{-1}$ seed rate with weedy check (83.33) followed by $200 \mathrm{~kg} \mathrm{ha}^{-1}$ seed rate with weedy check (81.66) (Table - 4 ).

Table 4.The effects seed rates and herbicides on days to heading in bread wheat

\begin{tabular}{llcl}
\hline Herbicides & \multicolumn{3}{c}{ Seed rates kg ha } \\
\cline { 2 - 4 } & 100 & 150 & 200 \\
\hline Agro2,4-D 720 g/1 & $73.33^{\mathrm{c}}$ & $71.66^{\mathrm{c}}$ & $71.66^{\mathrm{c}}$ \\
Pallas 45 OD & $71.66^{\mathrm{c}}$ & $73.33^{\mathrm{c}}$ & $71.66^{\mathrm{c}}$ \\
Derby 175 SC & $76.66^{\mathrm{c}}$ & $75^{\mathrm{c}}$ & $71.66^{\mathrm{c}}$ \\
Lancolet 450WG & $75^{\mathrm{c}}$ & $73.33^{\mathrm{c}}$ & $71.66^{\mathrm{c}}$ \\
Weedy check & $83.33^{\mathrm{a}}$ & $76.66^{\mathrm{bc}}$ & $81.66^{\mathrm{ab}}$ \\
\hline
\end{tabular}

LSD (5\%) 6.21

CV (\%) $\quad 4.99$

Means followed by the same letter in the lower case with in columns and rows are not significantly different from each other at $5 \%$ level of significance

The application of $100 \mathrm{~kg} \mathrm{ha}^{-1}$ seed rate with all herbicides revealed that statistically no significant difference except for weedy check and also the application of $200 \mathrm{~kg} \mathrm{ha}^{-1}$ seed rate with all herbicides revealed that statistically no significant difference except for weedy check. Furthermore, the application of all herbicides with increased seed rate $100 \mathrm{~kg} \mathrm{ha}^{-1}$ to $200 \mathrm{~kg} \mathrm{ha}^{-1}$ caused statistically no significant difference. The result revealed that earlier days to heading might be due to minimum crop weed competition. The delay in days to heading in weedy checks was probably due to severe competition for resources and also shading effects of weeds over crop for utilizing light. Tana et al. (2018) stated that no significant variation in days to heading due to the same variety used in the study.

Effects of seed rates and herbicides application on plant height in bread wheat

The main effects of seed rates and tested herbicides had no significant effect on plant height but the interaction of seed rates with herbicides brought significant effect on plant height. The maximum plant height was obtained from the interaction of $100 \mathrm{~kg} \mathrm{ha}^{-1}$ seed rates at weedy check plots $(111.08 \mathrm{~cm})$ followed by $200 \mathrm{~kg} \mathrm{ha}^{-1}$ seed rate with 
weedy check $(109 \mathrm{~cm})$ while the minimum plant height $(101.66 \mathrm{~cm})$ was obtained from the interaction effects of $200 \mathrm{~kg} \mathrm{ha}^{-1}$ seed rate with Pallas 45 OD (Figure 1).

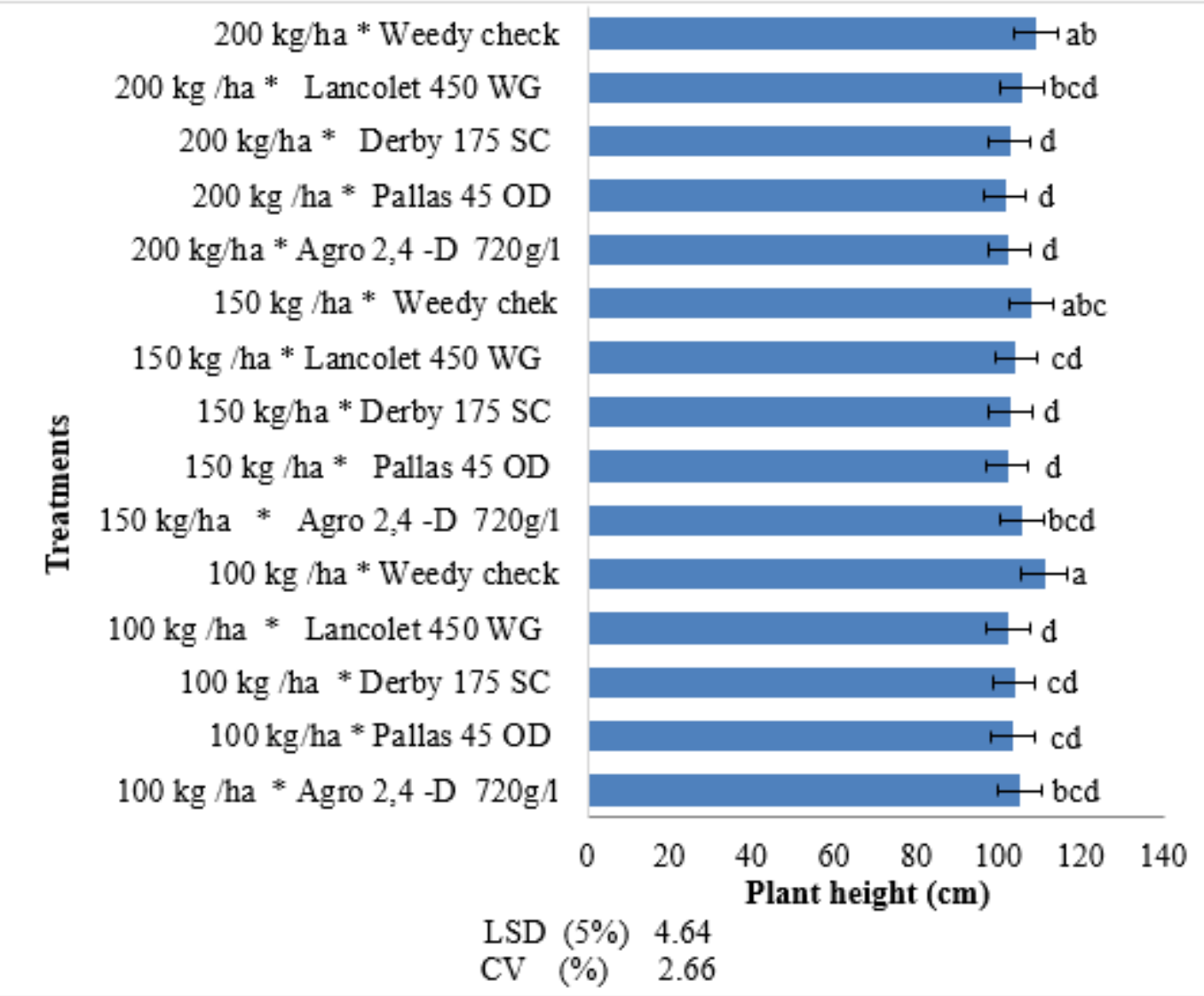

Means followed by the same letter in the lower case with in column chart are not significantly different from each other at $5 \%$ level of significance

Figure 2.The effect of seed rates and herbicides on plant height $(\mathrm{cm})$ in bread wheat

The application of $200 \mathrm{~kg} \mathrm{ha}^{-1}$ seed rate with 2, 4 - D $720 \mathrm{~g} / \mathrm{l}$, Pallas 45 OD and Derby $175 \mathrm{SC}$ showed that statistically no significant differences. Correspondingly, the combined use of $150 \mathrm{~kg} \mathrm{ha}^{-1}$ seed rate with Pallas 45 OD and Derby $175 \mathrm{SC}$ exhibited no significant differences. The tallest plants $100 \mathrm{~kg} \mathrm{ha}^{-1}$ seed rate with weedy check indicated that the competition of weeds. The result clearly showed that plant attained its maximum height where the competition was severe for light between crop as well as weed but at lower competition, plant could not invest larger resources to attain its maximum height. Similar findings was reported from Bibi et al (2008) who reported that in weedy check the wheat crop invested photosynthate in attaining the vegetative superiority by shading weeds. These findings was contradicted with the work reported by Khalil et al. (2009) who concluded that plant height is strongly under genetic control and but not affected by herbicides application. Plant height is a varietal character more affected by the genotype than by the environment. However, interaction of factors to some extent significantly altered plant height (Safdar et al., 2011).

\section{Effects of seed rates and herbicides application on spike length in bread wheat}

The main effects of different levels of seed rates and different herbicides application had no significant effect on the spike length of wheat while the interaction of different herbicides with different levels of seeding rates had significant effect on spike length. The highest spike length was recorded in application of Pallas 45 OD with 200 $\mathrm{kg} \mathrm{ha}^{-1}$ seed rate $(9.58 \mathrm{~cm})$ followed by the interaction of $150 \mathrm{~kg} \mathrm{ha}^{-1}$ seeding rate with Pallas $45 \mathrm{OD}(9.58 \mathrm{~cm})$ but the lowest spike lengths were recorded at weedy check plots that were caused by heavy weed infestation (Figure2). 


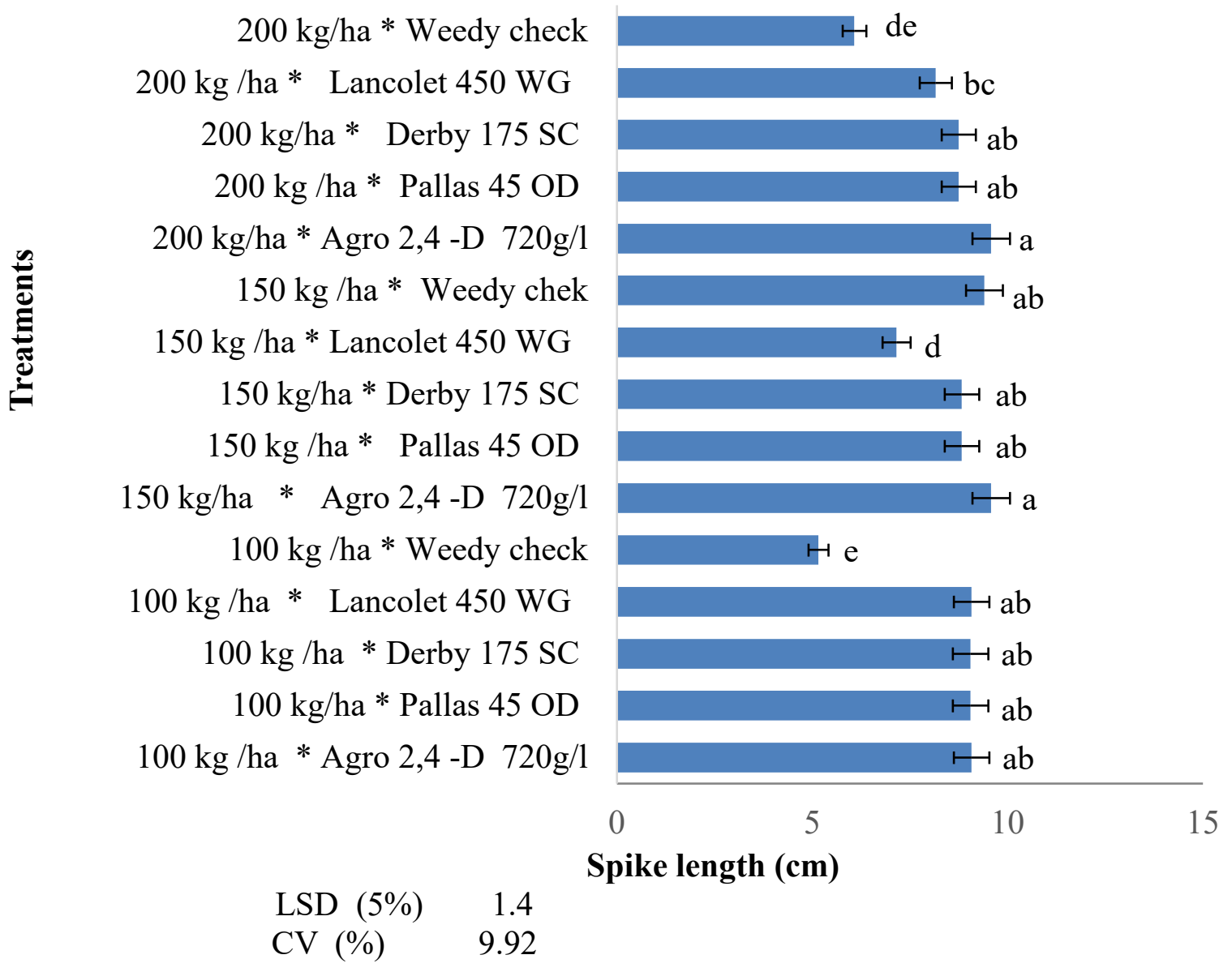

Means followed by the same letter in the lower case with in column chart are not significantly different from each other at $5 \%$ level of significance

Figure 3. The effects of seed rates and herbicides on spike length $(\mathrm{cm})$ in bread wheat

The interaction effects of all seed rates with all herbicides produced statistically no significant difference except for weed checks. The maximum spike length at $200 \mathrm{~kg} \mathrm{ha}^{-1}$ and $150 \mathrm{~kg} \mathrm{ha}^{-1}$ with Pallas $45 \mathrm{OD}$ could be related to little availability of space for weed growth that resulted in better growing conditions for the crop to utilize resources effectively to produce longer spikes but at weedy check due to severe competition shorter spikes produced.

Similar result was reported from Tana et al. (2018) continuous increase in spike length which might be attributed to relief of wheat plants from weed competition leading to better growing conditions and more resources availability to the wheat plants. Asad et al. (2017) also stated that increase in spike length attributed to minimum crop - weed competition in treated plots and more availability of moisture that cause healthy plant growth.

Effects of seed rates and herbicides application on grain yield in bread wheat

The grain yield was significantly affected by the application of different levels of seed rates and herbicides application. The interaction effects of different seed rates with different herbicides application were also highly significant (Table-5).Maximum grain yield was obtained at combination of Pallas 45 OD with $150 \mathrm{~kg} \mathrm{ha}^{-1}$ seed rate $\left(4516.42 \mathrm{~kg} \mathrm{ha}^{-1}\right)$ followed by interaction of Pallas $45 \mathrm{OD}$ with $200 \mathrm{~kg} \mathrm{ha}^{-1}$ seed rate $\left(4346.58 \mathrm{~kg} \mathrm{ha}^{-1}\right)$ while minimum grain yield $\left(1025 \mathrm{~kg} \mathrm{ha}^{-1}\right)$ was obtained from the combination of $100 \mathrm{~kg} \mathrm{ha}^{-1}$ seed rate with weedy check. 
Table 5.The effects of seed rates and herbicides on grain yield $\left(\mathrm{kg} \mathrm{ha}^{-1}\right)$ in bread wheat Herbicides Seed rates $\mathrm{kg} \mathrm{ha}^{-1}$

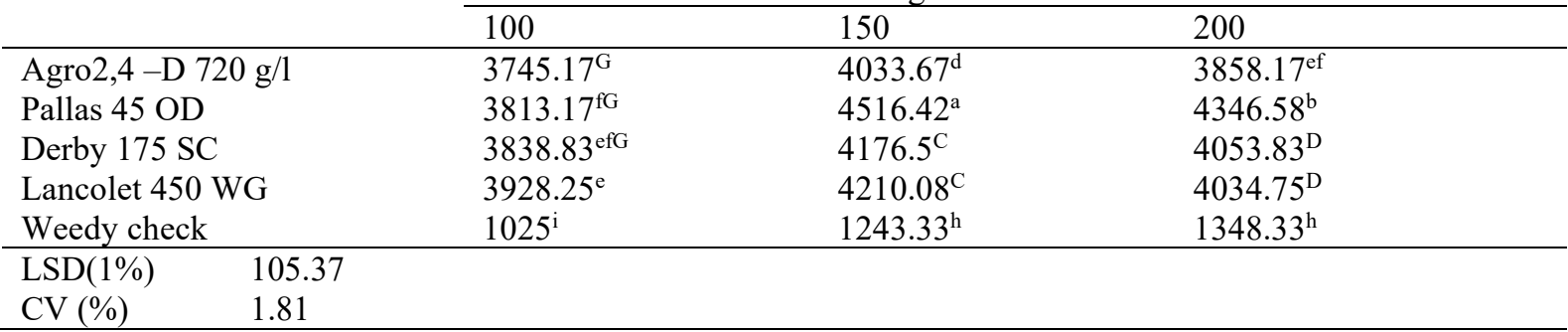

Means followed by the same letters in the upper case with in columns are not significantly different from each other at $1 \%$ level of significance

The application of Derby $175 \mathrm{SC}$ and Lancolet $450 \mathrm{WG}$ with $150 \mathrm{~kg} \mathrm{ha}^{-1}$ seed rate showed that statistically no significant difference and also interaction of $200 \mathrm{~kg} \mathrm{ha}^{-1}$ seed rate with Derby $175 \mathrm{SC}$ and Lancolet $450 \mathrm{WG}$ caused statistically no significant difference. The increased seed rates from $100 \mathrm{~kg} \mathrm{ha}^{-1}$ to $150 \mathrm{~kg} \mathrm{ha}^{-1}$ with interaction of all herbicides showed significant increase in grain yield. The highest number of grain yield at 150 $\mathrm{kg} \mathrm{ha}^{-1}$ seed rate with Pallas 45 OD could be related to less weed competition with crop for plant growth factors and optimum space for wheat plants to flourish and produce fertile tillers up to their potential, more number of seeds per spike, thousand grain weight and higher number of total biomass production. The herbicide also had the ability of controlling various weed species and persistent. However, the lower grain yield at weedy check treatments was due to the severe inter and intra specific competition that resulted in lower yield and yield components.

The result of this study was similar with Nadeem et al. (2006) which stated that different herbicidal treatments had a significant effect on grain yield of wheat. The greatest reduction of yield was occurred when no herbicide was applied. Increased in yield in herbicides treated plots were due to the efficient weed control and thus the crop utilized all the available resources. These results are in conformity with the work of Tunio et al. (2004) who reported that herbicidal treatments significantly increased grain yield in wheat. Ali et al. (2014) also stated that maximum grain yield was at weed free due to less weed population, better nutrient and water use efficiency but minimum at weedy check.

\section{SUMMARY AND CONCLUSION}

Bread wheat is one of major food grains that contain different nutrient and cultivated from small to large scale farmers in Ethiopia. Weed management practices such as optimum seed rates and promising herbicides are among the important methods for the management of weeds to improve wheat production and productivity. The integrated weed management practices such as optimum seed rates and herbicides nowadays advantageous than using single weed management practices for good weed control as well as obtaining maximum yield. Therefore, this study was designed to investigate the effects of seed rates and post emergence herbicides application on weed growth and productivity of wheat.

All of the traits studied were significantly affected by the interaction of different levels of seed rates with herbicides application. The minimum number of weed density, dry biomass of weeds and weed control efficiency were recorded at interaction of $150 \mathrm{~kg} \mathrm{ha}^{-1}$ seed rate with Pallas 45 OD but no weed control at weedy check while the maximum numbers of weed density and dry biomass were obtained from weedy checks.

The use of higher seed rates was effective as compared to lower seed rate $100 \mathrm{~kg} \mathrm{ha}^{-1}$ for weed control and obtaining maximum yield. The herbicides having the ability of controlling various weed species gave better yield advantages as well as for good weed management over narrow spectrum herbicides. Pallas 45 OD is recommended for controlling various weed species in wheat field at small scale and commercial farms.

\section{REFERENCES}

Abbas, S .H, Saleem,M., Maqsood, M. ,Mujahid,Y., Hassan ,M. and Saleem,R.,2009. Weed density and grain yield of wheat as affected by spatial arrangements and weeding techniques under rain fed conditions of Pakistan. Journal of Agricultural Science, 46(4):354-359

Ali,H., Tahir, M. and Nadeem,M.A.,2014.Determining Critical Period of Weed Competition in Wheat under Different Tillage Systems.life, 12(2) :74-79

Asad, M., Safdar, A., Ansar, M.R.,Ijaz, A., Suhaib, M. and Abuzar, M.K., 2017. Weed and Wheat Dynamics Preceding Different Herbicide. Pakistan Journal of Agricultural Research, 30(4):346-355.

Bibi,S., Marwat, K.B, Hassan ,G. and Khan, M.N, 2008. Effect of herbicides and wheat population on control of weeds in wheat.Pakistan.Journal of Weed Science Research, 14(3-4): 111-119

CSA.2018.Agricultural Sample Survey Series : Report on Area and Production for Major Crops(Private Holdings, Main Season).Statistical Bulletin No.586.Centeral Statistics Agency of Ethiopia, Addis Ababa, Ethiopia:15- 


\section{0}

Dalga ,D., 2016.Weed Dynamics and Yield of Bread Wheat (Triticum aestivum L.) in Response to Weed Management and Nitrogen Fertilizer Rates in Southern Ethiopia Sci. Agri. 16 (1), 2016: 8-19

Dixon, J., Braun ,H.J, Crouch, J.H., 2009. Overview: Transitioning wheat research to serve future needs of developing world. In Wheat Facts and Futures,1-25 Pp. Dixon, J. Braun, H.J. Kosina, P. and Crouch, J.H. (Eds). CYMMIT, Mexico.

Gomez,K.A.and Gomez ,A.A.,(1984).Statistical procedures for agricultural research (2 ed.). John wiley and sons, NewYork, pp. 680.

Hailu ,G.,2003. Wheat production and research in Ethiopia, IAR, Addis Ababa Ethiopia.

Khalil, Hassan, G., Ahmad ,H. and Sha,N.H, 2008. Individual and combined effect of different weed management practices on weed control in Wheat.Pakistan Journal of Weed Science Research,14(3-4): 131-139

Kolb,L.N.,Gallandt, E.R. and Mallory, E.B.,2012. Impact of spring wheat planting density, row spacing, and mechanical weed control on yield, grain protein, and economic return in Maine. Weed science, 60(2) :244253

Kristensen, E., Bouillon, S., Dittmar, T. and Marchand, C., 2008. Organic carbon dynamics inmangrove ecosystems: a review. Aquatic botany, 89(2) :201-219

Marwat, K. B., Muhammad ,S., Hussain,Z., Gul,B. and Rashid,H., 2008. Study of various weed management practices for weed control in wheat under irrigated condition

Nadeem,M.A.,Ali,A. and Tanveer,A.S.I.F.,2006. Effect of different weed control practices and fertilizer levels on the weeds and grain yield of wheat.Pakistan Journal of Botany, 39(1):173

Safdar, M.E., Asif, M., Ali, A., Aziz, A., Yasin, M., Aziz, M., Afzal, M. and Ali, A., 2011. Comparative efficacy of different weed management strategies in wheat. Chilean journal of agricultural research, 71(2):195-217

Shamsi, I., Jilani,H. G., Marwat,K. B., Mahmood,Q., Khalid ,S. and Hayat,Y. , 2006. Response of Poaceous Weeds in Wheat to PostEmergence Weed management practices. Pakistan Journal of Weed Science Research, 14(1-2): $1-8$

Stroud,A. and Parker,C.,1989.A weed identification guide for Ethiopia. A weed identification guide for Ethiopia : $55-78$

Tana,T.,Lemlem,M.and Dejene,M.,2018.Determination of Critical Period of Weed Competition in Bread Wheat Triticum aestivum L.at Haramaya,Eastern Ethiopia ,Doctoral dissertation,Haramaya University:1-92

Tunio, S.D., Kaka,S.N., Jarwar,A.D., Wagan,M.R, 2004.Effect of integrated weed management practices on wheat yield. Pakistan Journal of Agriculture Engineering and Veterinary Science, 20 (1):5-10 